УДК 141.7: 316.614

DOI https://doi.org/10.32837/apfs.v0i26.900

О. В. Запорожченко

ORCID ID: 0000-0003-0496-2605

кандидат філософських наук, доиент,

доиент кафедри права і соиіальної роботи

Ізмаӥльського державного гуманітарного університету

\title{
ІДЕНТИЧНІСТЬ ОСОБИСТОСТІ В УМОВАХ ІНФОРМАЦІЙНОГО СУСПІЛЬСТВА
}

Постановка проблеми. Стрімкий розвиток і поширення інформаційних технологій суттєво впливають як на соціокультурний простір загалом, так і на соціальне буття кожної людини. Традиційна ідентичність людини як істоти соціальної, що вступає у взаємодію із собі подібними в контексті звичних соціальних інститутів, піддається трансформації. Наприклад, основними особливостями інформаційного суспільства є гіперінформірованість, атомізація (фізичне роз'єднання) і віртуальний характер взаємодії, що особливо гостро відчувається через світову пандемію COVID-19. Розширення доступу до інформації та інформаційна рівність стає метою глобальної соціальної політики. Потоки абсолютно різнорідної, несистематизованої інформації обвалюються на людину зі всіляких гаджетів, які цілодобово під'єднані до Інтернету. Отже, зараз інформація цілком може бути подана у вигляді загальної основи структурування соціокультурного простору. Інформаційний простір, у якому ми перебуваєм, - це, по суті, створена людьми віртуальна реальність, що складається з безлічі малоцінних копій, повторів, інтерпретацій тощо. Водночас ідентичність як встановлення тотожності завжди передбачає устремління до певної основи, єдиного і більшменш стабільного початку. У пізнавальній або практичній діяльності людини встановлення тотожності або ідентичності є необхідною умовою істинності. У ролі ідентифікованих об'єктів можуть виступати прояви буття різного рівня реальності, цінності і складності, зокрема суспільство й людина. В останньому випадку виникає необхідність самоідентифікації як порівняння себе із самим собою і іншим, зовнішнім, глибинним або граничним. Для традиційних суспільств інформація статична і позачасова, усі ті ж символи і знаки виявляються в циклічно мінливому природному і соціальному світі. Нова інформація осмислюється в межах певної традиції: звичних міфів і релігійних вірувань, усталених практик та світоглядних парадигм. Постмодернізм з його установкою на невизначеність і мінливість позбавляє людину ціннісних орієнтирів, світоглядної основи й ускладнює ідентичність. Отже, є важливим простежити зв'язок між інформацією та трансформацією ідентичності людини. Цінності глобального інформаційного суспільства переглядаються 3 позицій перш за все інфобезпеки людини в стані кризового соціуму. Соціальна екологія сьогодні набуває вирішального характеру. Від націоспрямованої ідентичності української людини залежить поступ нашої держави.

Стан розробленості проблеми. Витоки осмислення проблеми ідентичності в соціально-філософському контексті слід шукати у філософів і соціологів Заходу: Макс та Альфред Вебери, О.Шпенглер,Г.Зімель,А.Тойнбі, Х.Ортега-і-Гасет, К. Мангайм, Е. Гусерль, К. Ясперс, А. Швейцер та ін. Дослідження характеристик та тенденцій розвитку постіндустріального, інформаційного суспільства розпочалося і здобуло поширення в працях Д. Белла, 3. Бжезинського, Дж. Ваттімо, Р. Гароді, А. Горца, Р. Дарендорфа, М. Кастельса, П. Козловськи, Р. Каца, М. Маклюена, С. Малле, Й. Масуди, Е. Тофлера, Е. Сміта, Т. Стоуньеpa, А. Турена, Ф. Уебстера та ін. До досліджень також долучилися вітчизняні дослідники О. Артюшенко, С. Даниленко, О. Данильян, О. Дзьобань, С. Жданенко, В. Кондрусєва, Н. Лазарович, М. Лукашенко, Л. Макаренко, А. Меньшеніна, Л. Мудрак, А. Назарчук, М. Онопрієнко, Ю. Петрухно, В. Пожуєв, В. Політанський, В. Поперечнюк, О. Проскуріна, К. Райда, І. Рєшетнікова, Л. Рижко, О. Селезньова, В. Скиртач, О. Шевчук, М. Шмиголь, В. Щербина, М. Яруш, К. Яценко та ін., які акцентували свою увагу на виокремленні істотних змін в структурі, світогляді, взаємодії особистості в інформаційному суспільстві. Для нас це має значення в сенсі трансформацій у свідомості індивіда. В подальшому були зроблені дослідження в галузі особливостей «суспільства знань», «мережевого суспільства» тощо.

Е. Тоффлер розглядав питання про можливі ризики інформаційного суспільства, вказуючи на його загрозливі фактори для людини як соціальної істоти; стверджуючи, що, з одного боку, інтелектуалізація умов праці, розосередження комп'ютерів по домівках, $є$ наступним кроком до створення простору інтелектуального середовища; з іншого, виникає небезпека щодо поглинання людської свідомості інтелектуальними машинами, об'єднаними в комунікаційні мережі. На його думку, цивілізація «Третьої хвилі» заохочує індивідуальний 
розвиток, але при цьому збільшується соціальна різнорідність, що пояснює феномен самотності, оскільки саме індивідуалізоване самовираження посилює ізольованість [16].

М. Кастельс висловлює припущення відносно того, що нова комунікаційна система радикально трансформує простір і час, фундаментальні виміри людського життя; усталені місця позбавляються свого культурного, історичного, географічного значення та реінтегруються у функціональні мережі або в образні колажі, викликаючи до життя простір потоків, які змінюють простір. Звідси моделюється потреба в людині «нового типу» - з'являються запити на само-програмування; моделюється пристосовування до умов, які постійно змінюються; вимальовується здатність знаходити собі місце у нових проектах, в яких треба спиратися не на зв'язки і позиції у корпоративній бюрократії, а на особисті мережеві контакти. Філософ заглиблюється в пошуки взаємозв'язків між глобалізацією та ідентичністю, між мережею та індивідуальним «Я». У цьому зв'язку він підкреслює, що у світі, де відбуваються неконтрольовані зміни, люди схильні групуватися навколо первинних джерел ідентичності, зокрема: релігійних, етнічних, територіальних, національних. Водночас люди дедалі частіше організовують свій зміст не навколо того, що вони роблять, а на підставі того, ким вони є, або на основі своїх уявлень про те, ким вони є [10].

Д. Белл відзначив той факт, що жоден біологічний організм або людська спільнота не можуть зазнати змін в розмірах та, відповідно, в масштабах, не змінюючи своїх форм та структури. Таким чином, стається суперечливий процес: з одного боку, комп'ютерні технології провокують глобалізацію, яка розповсюджується у загальнолюдських масштабах та безпосередньо впливає на характер міжособистісного спілкування. 3 іншого, індивідуалізація «замикає» особистість перед монітором комп'ютера; створює стан самоізоляції від культурних контактів. Безумовні величини - людина, суспільство - розглядаються тепер як значною мірою дезавуйовані процесами сучасних глобальних перетворень [2]. Відображенням першого є дискурс трансгуманізму та постлюдства (Дж. Холдейн, Р. Курцвейл, Р. Етінгер та інші), другого - заперечення реальності суспільства на користь простих «множин», «роїв» чи інших конгломератів спільності.

Еволюція проблеми ідентичності особистості в суспільстві від появи перших зародкових теоретичних форм до самостійного теоретичного знання досліджується в роботах класиків зарубіжної філософії, психології та соціології: У. Джеймса, 3. Фрейда, К. Юнга, Ж . Піаже, Е. Фромма, Дж. Міда, Ч. Кулі, Е. Еріксона, А. Маслоу, Р. Мейлі, Ю. Габермаса, К. Хорні та багатьох інших. Водночас вивчення цієї проблеми дає змогу констатува- ти, що, незважаючи на наявну теоретичну базу досліджуваних феноменів, їхня рефлексія в умовах інформаційного суспільства, специфічного місця в цій системі України, потребує уточнень з урахуванням нових інформаційно-технологічних процесів.

Мета дослідження - показати основні напрями трансформації ідентичності особистості в умовах глобалізації інформаційно-знаннєвого простору.

Виклад основного матеріалу. Із соціально-психологічного погляду ідентичністю вважається стан самореалізації, самоотожнення особистості в певних соціальних умовах. У філософії ідентифікація розуміється як вища форма соціалізації індивіда; стан співвідносин людини із соціумом через ототожнення себе 3 колективними сутностями локальної цивілізації, культури, історичної доби. Так реалізується соціальний набір статусів i ролей індивіда - через потреби, мотиви, настанови, і на найвищому рівні індивідуального розвитку - цінності. У глобальному інформаційному суспільстві стається трансформація ідентичності на новітніх засадах. Унаслідок інтенсифікації інформаційного обміну із оточенням, експоненціального збільшення кількості соціальної інформації, світоглядні орієнтири особистості набувають стану плинності. Розмаїтість, ціннісна аморфність інформації провокує маргіналізацію участі людини у творенні і самовідтворенні нових сенсів, нового знання. Генератори інформації в суспільстві перетворюються на її редакторів; більше того, невидимі підслуховуючі та підглядаючі програми контролюють і корегують інформаційний обмін, що провокує появу різних конспірологічних теорій стосовно маніпуляції масовою свідомістю. Внаслідок цього процес індивідуалізації та персоналізації особистості в інформаційному потоці набуває форми трансформації особистісної ідентичності. 3 одного боку, Інтернет через комунікаційні канали дозволяе користувачам різних переконань, різного походження й рівня освіченості встановлювати контакт один з одним і об'єднуватися у співтовариства. 3 іншого, проблема ідентифікації та анонімності користувачів, збуджує сумнів в їхній здатності повноцінно розуміти свою життєдіяльність (як приватну, так і професійну) і розпоряджатися нею у віртуальному середовищі. В інформаційному середовищі людина стикається 3 декількома видами ідентичності, що трансформуються внаслідок впливу інформаційно-комунікаційних технологій (IКT): ipse-ідентичність (відчуття власної особистості) та idem-ідентичність (формальна ідентичність, що залежить від контексту, оточення й ситуації) [5, с. 18-20]. Комп'ютерні системи накопичують знання, створюють профілі, здійснюючи внесок в idem-ідентичність користувача, який не підозрює відносно цих профілів і того, як вони впливають на його ipse-ідентичність. Світ особистості 
вводиться у всепоглинаючий безособовий віртуальний світ і тому свідомість втрачає самостійність, відсторонюється від наслідків безвідповідального ставлення до себе та зовнішньої по відношенню до неї інформації. Сучасна суспільна світоглядна настанова полягає в тому, щоб інформаційне суспільство зміцнювало ipse-ідентичність як вихідну точку для idem-ідентичності. Так формується соціальна відповідальність за стан духовного і психічного здоров'я користувачів 3 точки зору застосування масофікованої інформації.

3 іншого боку, у людини з'являється вибір вищого гатунку - вибір шляхів індивідуальної творчості. Проблема тепер полягає в тому, наскільки ці шляхи адекватні суспільному вибору в певній ситуації: політичній, економічній, культурній і соціальній. Сучасна трансформація ідентичності особистості полягає у формуванні індивідуального соціального часопростору; висуває підвищені вимоги до відповідальності за своє життя і життя оточуючих; до можливості ідентифіковано розпоряджатися своїм етичним, емоційним, фізичним, емоційним досвідом, щоб бути самостійною особистістю. Кризовий стан українського суспільства вимагає від особистості прикласти усі зусилля, щоб зберегти себе і загальний потенціал народу.

Парадоксальність сутності інформаційного суспільства виявляється також у різнополярних трактуваннях явища «самотність», що є одним із сегментів ідентичності: з одного боку, інформатизація соціуму об'єднує людей, а з іншого - все більше трансформує його в суспільство тотальної самотності. Емоційні почуття і відчуття людей стають поверхневими і витісняються нереальними, віртуальними. Інформаційна комунікативність, що забезпечує доступність різноманітної інформації, і реальна роз'єднаність людей, вступають у протиріччя, створюють проблеми суб'єктивізму, особистісного вибору інформації та їі трансформації у поведінкові регулятиви, загострюють проблему деформації загальнолюдських цінностей $[9$, с. $56 ; 14$, с. 210$]$.

Інформаційні технології сприяють інтеграції світу в глобальних мережах і одночасно викликають руйнацію соціально-комунікаційних етнічних, релігійних, інших бар'єрів світоглядного типу. У результаті безпосередньої комунікації індивіда 3 джерелом інформації відбувається інтенсифікація процесу персоналізації, коли людина стає менш залежною від загальноприйнятої, традиційної думки, системи поглядів, тощо, у сприйнятті та інтерпретації інформації. Головним наслідком процесу персоналізації стає розмивання соціальних ролей, руйнування минулих ідентичностей, у результаті чого людина, як вказує Ж․ Ліповецкі, постає немовби «плаваючий простір, що не має ані постійного місця, ані орієнтирів» [12, с. 35]. Формуються нові типи і види ідентичності, нові спільноти, кордони між якими стають легко проникними й рухливими.

Отже, інформаційне суспільство є необмеженим часопростором для самоконструювання особистості, з одного боку, розширюючи простір ідентифікації, а з іншого, звужуючи саму ідентичність відповідно до завдань з боку редакторів інформації. Так фрагментується самість, формується поліідентичність. Це, зі свого боку, призводить до зростання в житті людей ролі різного роду симулякрів - образів реальності, які заміщають саму реальність, «...локальні культури й ідентичності втрачають коріння і замінюються символами товарного світу, взятими з рекламного та іміджевого дизайну мультинаціональних концернів. Буття стає дизайном. Симуляція соціальних інститутів є фактором і симптомом розречевлення суспільства, котре формує образи, опис яких призводить до використання віртуальної реальності і передбачає взаємодію людини не з речами, а з їх образами [7, с. $12 ; 8$, с. 14]. Людина інформаційного суспільства занурюється у віртуальну реальність симуляцій і все більшою мірою сприймає світ як ігрове середовище, усвідомлюючи його умовність, керованість його параметрів і можливість виходу з нього [15, с. 326-330].

У розробленій Йоханом Хейзінгою концепції ігрова діяльність є одним 3 основних архетипів людського самовираження і взаємодії. Саме він ввів у соціальну філософію термін Homo ludens (людина граюча) [18]. Така людина мало обтяжена вантажем сформованих та історично обумовлених стереотипів; володіє більш мобільними реакціями і здатністю маніпулювати будь-якими пластами інформації; набуває нової абстрактної форми свого існування. Втрачається їі індивідуальність; тепер залишаються лише ролі-ідентичності, виникає бажання абсолютного копіювання самої себе. Тому соціокультурний простір Же. Бодріяр називає «ксероксом культури». Прикладом «нарцисичного некрозу» він називає клонування; по суті, це той самий ксерокс, тільки «ксерокопіюється» сама людина. Водночас цікаво, маси теж є клонічним агрегатом, який працює від тотожного до тотожного, без звернення до іншого [3, с. 298-230]. Отже, у цьому сенсі ідентичність є продуктом принципу симуляції, за яким усі знаки можуть обмінюватися один на одного, але це не торкається реальності: «Тепер всі роз'єднані й байдужі під владою телебачення і автомобіля, під владою моделей поведінки, відображених у всьому - в передачах мас-медіа або ж у плануванні міст... Усе збудовано в ряд і кожен несвідомо ототожнює себе з уміло розставленими напрямними симулятивними моделями. Всі допускають взаємну підстановку, як і самі ці моделі... Фактично форму суспільних відносин утворює дифузно присутня у всіх тканинах міст монополія коду» [11, с. 157]. «Надлишок» видимості, ха- 
рактерний для інформаційного суспільства, призводить, як писав П. Козловскі, до руйнування сцени відомого, сфери вираження, повної прозорості й безтілесності дійових осіб, тобто до втрати «Я»...» $[11$, c. 158$]$.

Прагнення людини вирватися за межі своєї природної сутності накладає відбиток на суто людське. У новому віртуальному просторі людина стає своєрідною призмою, крізь яку проглядається будь-яка реальність. Тому в розв'язанні соціальних завдань, спрямованих на благо людського існування, необхідною є безпосередня участь самої людини; невблаганно зростає її відповідальність за результати соціальних дій. Ю. Габермас підкреслює, що ротації світогляду інформаційного суспільства сприяють зміні характеристик ідентичності, розуміння людиною самої себе залежить не тільки від того, як вона сама себе описує, а й від тих зразків, яких вона дотримується. Самототожність Я визначається одночасно тим, як люди себе бачать і якими вони хотіли б себе бачити [17]. Усвідомлюючи себе суб'єктом діяльності, людина бере на себе авторство свого соціального життя і моральну відповідальність за нього. Згідно зі сформованим рівнем довіри до себе людина займає ту чи іншу життєву позицію. У процесі міжособистісних комунікацій на інформаційній основі людина отримує додаткову інформацію про себе, а зіставивши себе з безліччю інших людей, вона може зрозуміти себе, усвідомити, якою вона є насправді. У цьому сенсі Ю. Габермас зазначає, що ідентичність особистості формується за допомогою самоідентифікації, яка отримала інтерсуб'єктивне визнання. Так людина проходить шлях новонароджень і перероджень [17].

Висновки. Світ глобального суспільства - суспільства інформації і новітніх знань, є для сучасної людини джерелом її соціальної ідентифікації. Сучасна поляризація світу відносно застосування надбань інформаційної доби вимагає від особистості прискореної ідентифікації в суспільно-соціальних стосунках. Психонервова система сучасної людини знаходиться в стані постійного напруження: інформаційні перенавантаження виснажують людський потенціал. Особливо це стосується життя українського соціуму. Загальнолюдські цінності залишаються ідеалом, а буденне життя вимагає ідентифікованої адаптації до умов життя в кризовому соціумі.

Зусилля вчених, людей інтелектуального гатунку повинні бути спрямовані на виховання дітей та молоді в дусі постійного пошуку індивідуального шляху у сполученні загальнолюдських, регіональних і колективних цінностей. Для цього треба постійно корегувати апарат засобів світоглядного характеру стосовно сприйняття, відчуття і розуміння сучасної ситуації. Соціальна відповідальність в кризових умовах повинна бути спрямована на забезпечення, перш за все, інфобезпеки самого себе і оточуючих. Сучасні катастрофи, соціальні негаразди, через позитивно спровоковану інформацію, повинні сприйматися ідентично до самовідчуття людини. Роблячи свій вибір в світі інформації, людина повинна пам'ятати про наслідки своїх дій - вербальних і невербальних. Соціальна відповідальність - індивідуальна і колективна, стає синонімом виживання людства в сучасних умовах.

0. Інформаційне суспільство: джерела, проблеми, тенденції розвитку. Гілея: на уковий вісник. 2016. Вип. 110. С. 177-180. URL: http://nbuv.gov.ua/UJRN/gileya_2016_110_45.

2. Белл Д. Грядущее постиндустриальное общество. Опыт социального прогнозирования. Пер. с англ. Москва : Academia, 1999. 959 с.

3. Бодрийяр Ж. Соблазн / пер. с фр. А. Гараджи. Москва : Ad marginem, 2000. 317 с.; Бодрийяр Ж⿱ Символический обмен и смерть / пер. с фр. и вступ. ст. С.Н. Зенкина. Москва : Добросвет, 2000. 389 с.

4. Гидденс Э. Ускользающий мир. Как глобализация меняет нашу жизнь. Москва : Весь мир, 2004. $120 \mathrm{c}$.

5. Данильян О. Інформаційне суспільство: морально-етичний дискурс. Інфорлащія $i$ право. 2014. № 1. C. 16-25. URL: http://nbuv.gov.ua/UJRN/ Infpr_2014_1_4

6. Данильян 0., Дзьобань О. «Симулякр»: концептуалізація феномена у постнеокласичній філософії. Інфорлащія і право. 2016. № 2 (17). С. 66-76.

7. Дзьобань О., Соснін О. Інформаційне суспільство як мережево-комунікативний простір управління. Віче. 2015. № 10. С. 7-13. URL: http://nbuv.gov.ua/ UJRN/viche_2015_10_3;

8. Дзьобань О., З Жданенко С. Соціокультурний простір інформаційного суспільства як середовище буття сучасної людини. Вісник Національного університету «Юридична акаделія України імені Ярослава Мудрого». Серія: Філософія, філософія права, політологія, соціологія. 2014. № 2 (21). С. 12-21.

9. Доній Н. Самотність як територія ризику суспільного життя людини. Філософія $і$ політологія в контексті сучасної культури. 2014. Вип. 7. С. 55-60.

10. Кастельс М. Информационная эпоха: экономика, общество и культура / Пер. с англ. под науч. ред. О. И. Шкаратана. Москва : ГУ ВШЭ, 2000. 608 с.

11. Козловски П. Культура постмодерна / пер. с нем. Москва : Республика, 1997. 238 с.

12. Липовецки Ж. Эра пустоты: Эссе о современном индивидуализме / пер. с фр. В.В. Кузнецова. СанктПетербург : Владимир Даль, 2001. 330 с.

13. Лукашенко М.В. Інформаційне суспільство та становлення віртуальної соціальності. Гілея: науковий вісник. 2017. Вип. 122. С. 280-283. URL: http://nbuv.gov.ua/UJRN/gileya_2017_122_71.

14. Помазова О.В. Самотність як психологічний феномен. Наукові записки Національного університету «Острозька академія». Сер. Психологія і педагогіка. 2013. Вип. 23. С. 206-214. 
15. Сучасне суспільство : філософсько-правове дослідження актуальних проблем : монографія / О.Г. Данильян, О.П. Дзьобань, С.Б. ЖАданенко та ін.; за ред. О.Г. Данильяна. 2-ге вид., перероб. і допов. Харків : Право, 2017. 416 с;

16. Тоффлер Э. Третья волна. Москва : 000 «Фирма «Издательство АCТ», 2010.

17. Хабермас Ю. От картин мира к жизненному миру / пер. с нем. Д. Мироновой. 2-е изд. Москва : Идея-Пресс, 2011. С. 49-71.

18. Хейзинга Й. Homo Ludens. В тени завтрашнего дня / пер. с нидерл. В. Ошиса. Москва : АСТ, 2004. 539 с.

\section{Анотація}

Запорожченко О. В. Ідентичність особистості в умовах інформаційного суспільства. - Стаття.

Статтю присвячено проблемі впливу інформаційних технологій на ідентичність особистості. Такі ключові особливості сучасності, як стрімкий розвиток і поширення інформаційних технологій, істотно впливають як на соціокультурний простір загалом, так і на соціальне буття кожної людини. Постійне збільшення обсягів інформації, що «бомбардує» свідомість людини, щораз більша соціальна атомізація і віртуалізація соціальних зв'язків визначають формування нового типу ідентичності, який треба вивчати з погляду різних дисциплін: соціальної філософії, соціології, соціальної психології, педагогіки тощо. У цій статті зроблено спробу соціально-філософського аналізу основних аспектів трансформації ідентичності в умовах інформаційного суспільства. Справді, стрімкі зміни в комплексі інформаційних технік і технологій - це ні 3 чим не порівнянний виклик, оскільки людині доводиться мати справу з інформацією, яка часто має безсистемний, маніпулятивний характер, спрямована на те, щоб сформувати потреби, переконання, мотиви для досягнення певних економічних і політичних цілей, які лежать за межами справжніх, автентичних потреб особистості.

Ситуація ускладнюється також викликами і загрозами зовнішньополітичного характеру. Завдання, які стоять тепер перед гуманітарними науками, полягає в тому, щоб дослідити процеси, що відбуваються в сфері «людина-інформація»; надати державним структурам систему методологічних позицій у сфері інформаційної безпеки людини і світоглядних основ ідентифікації особистості в кризовому соціумі. Отже, соціальна інформаційна екологія сьогодні набуває вирішального значення, а від формування автентичної особистості, здатної відповідати на виклики сучасності, залежить подальший прогрес суспільства.

У статті розглядаються базові ідеї основних зарубіжних теоретиків інформаційного суспільства, особливості їх осмислення вітчизняними дослідниками в контексті системи «інформація-культура-суспільство-людина». Окрема увага в статті приділяється саме змінам у структурі, особливостях, чинниках формування ідентичності особистості. У статті автор розглядає як позитивні, так і негативні аспекти про- блеми ідентичності особистості в умовах формування інформаційного суспільства, намагається окреслити напрями подальшого вивчення проблеми ідентичності, приділяє водночас особливу увагу трансформаціям у системі цінностей «людини інформаційної» .

Ключові слова: особистість, ідентичність, інформаційне суспільство, глобалізація, трансформація, свідомість, світогляд.

\section{Summary}

Zaporozhchenko $O . V$. Individual's identity in the conditions of information society. - Article.

The article is devoted to the problem of the information technology impact on the personality identity. Such a key feature of our time as the rapid development and spread of information technologies significantly affects both the socio-cultural space as a whole and the social life of each person. The constant increase in the amount of information that "bombards" human consciousness, the growing social atomization and virtualization of social ties determine the formation of a new type of identity which should be studied from the point of view of various disciplines - social philosophy, sociology, social psychology, pedagogy, etc. This article is an attempt at a socio-philosophical analysis of the main aspects of the identity transformation in the information society. Indeed, rapid changes in the complex of information engineering and technologies are an incomparable challenge, since a person has to deal with the information that is often unsystematic and manipulative in nature, often aimed at forming needs, beliefs, and motives that serve achieving certain economic and political goals that lie outside the individual's true and authentic needs.

The situation is also complicated by challenges and threats of a foreign policy nature. The challenge now facing the humanities is to investigate the processes occurring in the field of "human-information" interaction; to provide state structures with a system of methodological positions in the field of human information security and the ideological foundations of the personality identification in a crisis society. Thus, social information ecology today is acquiring decisive importance, and the further progress of society depends on the formation of an authentic personality capable of responding to the challenges of our time.

The article examines the basic ideas of the main foreign theorists of the information society and examines the features of their interpretation by domestic researchers in the context of the "information-culture-societyman" system. Special attention is paid to the changes in the structure, characteristics, and factors of the personality identity's formation. In the article, the author examines both positive and negative aspects of the problem of personal identity in the context of the information society's formation, tries to outline the directions for further study of the problem of identity, while paying special attention to transformations in the value system of the "information man."

Key words: personality, identity, information society, globalization, transformation, consciousness, worldview. 